\title{
RECOVERY OF CONTAMINATED SINGLE-PHASE DETERGENT BY MEANS OF MEMBRANE FILTRATION
}

\begin{abstract}
The results of the purification of contaminated cleaning solutions (acidic single-phase detergent), emanating from a diary industry, with the use of NF and UF flat-sheet membranes have been reported. The studies have shown potential usefulness of membrane filtration for the recovery of spent acid single-phase detergent. The NF (NP030 and NP010) and the tight UF (PS1) membranes provided high separation of specific milk components (protein and lactose) and organic matter, expressed as TOC and COD. The purified detergent maintained its low $\mathrm{pH}$ value and high value of acidity. However the surface tension slightly increased as a result of the high separation of the anionic surfactant.
\end{abstract}

\section{INTRODUCTION}

Cleaning-in-place (CIP) is an important unit operation in the food industry which ensures a constant product quality, efficient heat transfer in heat exchangers and avoids growth of microorganisms [1-3]. To meet the requirements of high standards of hygiene, the dairy industry consumes a large quantity of water and chemicals. A typical dairy CIP process consists of flushing with water, washing with alkalis and acids, followed by disinfection. Finally, the equipment is rinsed with water and dried. Cleaning solutions may be discharged into the sewage system after one use (single-use systems), or are used several times (multi-use systems) [4].

Environment protection against harmful effects of aggressive chemicals as well as the need for reducing water consumption forced changes in production line cleaning. Conventional methods for cleaning, using alkalis and acids, are gradually being replaced by single-phase detergents. The composition of such a washing detergent inte-

*Wrocław University of Technology, Institute of Environment Protection Engineering, Wybrzeże Wyspiańskiego 27, 50-370 Wrocław, Poland, e-mail: izabela.kowalska@pwr.wroc.pl 
grates alkalis or acids, surfactants, complexing and disinfecting agents, and defoamers. Using a complex formula of single-phase detergent reduces the cleaning time, as well as the amount of both water and chemicals.

The literature reports indicate that membrane processes (NF $[2,5,6], \mathrm{UF}[7,8]$ and MF [9]) are considered as one of the leading technologies for the purification and recovery of cleaning solutions although the research focuses mainly on the purification and recovery of sodium hydroxide and nitric acid. From among reports discussing the recovery of acids used in the dairy industry, we should mention the following studies [9-11]:

Novalic et al. [10] showed that $\mathrm{NF}$ (35\% retention of $\mathrm{NaCl}$ from $5 \%$ solution) was suitable for the recovery of acidic cleaning solutions. For polluted acid, with the COD value of $1800 \mathrm{~g} \mathrm{O}_{2} / \mathrm{m}^{3}$, purification on the level of $93 \%$ was achieved. The cross-flow velocity had no influence on the performance of the NF membrane, whereas the flux enlarged linearly with increasing pressure.

Dresch et al. [9] revealed that the recovery of CIP acid by means of UF (300 kDa) was not very satisfactory ( $20-50 \%$ reduction of COD), whereas the NF was considered to be a more appropriate purification process even at low transmembrane pressures. It has been shown that MF, applied as a pre-treatment process, deteriorated the NF performances.

Räsänen et al. [11] studied the purification of spent nitric acid $\left(C O D=100-300 \mathrm{~g} / \mathrm{m}^{3}\right)$ with the use of the Desal 5 DL membrane. It was shown that NF, with relatively low recovery of permeate, gives $88 \%$ of initial nitric acid concentration in the permeate.

The paper reported the purification of contaminated cleaning solutions. Flat-sheet UF and NF membranes differing in MWCO were evaluated for their potential use in the recovery of an acidic single-phase detergent. The polymers have been used mainly for the purpose of: (i) long-term evaluation of membrane hydraulic performance; (ii) assessment of the fouling tendency; (iii) evaluation of the quality of the recovered solution in comparison with the fresh detergent; and (iv) assessment of the chemical stability of a polymer material.

\section{MATERIALS AND METHODS}

Feed solutions. A liquid acidic detergent, tailor-made for CIP systems in the dairy industry, was used. The single-phase detergent was composed mainly of nitric acid and peroxyacetic acid, with the addition of low-foaming surfactants. The filtration experiments were conducted for the following solutions: (i) $1-4 \% \mathrm{w} / \mathrm{v}$ aqueous solution of a single-phase detergent; (ii) $0.75 \% \mathrm{w} / \mathrm{v}$ aqueous solution of milk with a fat content of $3.2 \% \mathrm{w} / \mathrm{v}$; and (iii) $2 \% \mathrm{w} / \mathrm{v}$ aqueous solution of a single-phase detergent, to which $0.75 \% \mathrm{w} / \mathrm{v}$ of milk was added to simulate industrial conditions. 
Filtration experiments. The filtration experiments were carried out using flat-sheet membranes, which are characterized in Table 1. Owing to the acidic nature of the test solutions, polymers that showed high resistance to chemical agents were selected for the initial tests.

Table 1

Characteristics of membranes

\begin{tabular}{|c|c|c|c|c|c|}
\hline Membrane & $\begin{array}{l}\text { Polymer } \\
\text { material }\end{array}$ & $\begin{array}{c}\text { MWCO } \\
{[\mathrm{kDa}]}\end{array}$ & $\begin{array}{c}\mathrm{Na}_{2} \mathrm{SO}_{4} \\
\text { retention } \\
{[\%]}\end{array}$ & $\mathrm{pH}$ range & $\begin{array}{c}\text { Maximum } \\
\text { temperature }\left[{ }^{\circ} \mathrm{C}\right]\end{array}$ \\
\hline NP030 & \multirow{2}{*}{ PES } & & 80-95 & $0-14$ & \multirow{5}{*}{95} \\
\hline NP010 & & & $25-55$ & $0-14$ & \\
\hline PS1 & PS & 1 & & $0-14$ & \\
\hline UP005 & \multirow{2}{*}{ PES } & 5 & & $0-14$ & \\
\hline UP010 & & 10 & & $0-14$ & \\
\hline
\end{tabular}

Ultrafiltration and nanofiltration membranes with the surface area of $4.53 \times 10^{-3} \mathrm{~m}^{2}$ were tested in Amicon 8400 filtration cells, with the total capacity of $3.5 \times 10^{-4} \mathrm{~m}^{2}$. The transport and separation properties of the membranes were examined at of $20^{\circ} \mathrm{C}$ and transmembrane pressures of 3 bar. To minimize the thickness of the polarization layer on the membrane surface, the solution was mixed at the speed of $300 \mathrm{~min}^{-1}$.

Rejection and flux decline analysis. The criteria for assessing the effectiveness of the filtration process are the following parameters, listed in Table 2.

Table 2

Criteria for assessing the efficiency of the membrane process

\begin{tabular}{|l|c|c|c|}
\hline \multicolumn{1}{|c|}{ Parameter } & Equation & Unit & No. \\
\hline Retention coefficient & $R=1-\frac{C_{p}}{C_{f}} \times 100$ & $\%$ & $(1)$ \\
\hline Permeate flux & $J=\frac{1}{A} \frac{d V}{d t}$ & $\mathrm{~m}^{3} \cdot \mathrm{m}^{-2} \cdot \mathrm{s}^{-1}$ & $(2)$ \\
\hline Relative flux & $R F=\frac{J}{J_{w}} \times 100$ & $\%$ & $(3)$ \\
\hline Flux recovery & $F R=\frac{J_{f}}{J_{w}} \times 100$ & $\%$ & $(4)$ \\
\hline
\end{tabular}

From the above flux definitions, the intensity of fouling was calculated. The value $100-R F$ is a measure of the flux decline during membrane filtration. The value 
$1-F R$ corresponds to the flux decline of the membrane caused by irreversible fouling (defined as a part of fouling not removable by rinsing and backwashes, but only by chemical cleanings). Furthermore, the value $F R-R F$ corresponds to the flux decline of the membrane caused by reversible fouling.

Analytical methods. The feed solutions and the permeates collected from the filtration runs were subjected to physicochemical analyses. The conductivities and $\mathrm{pH}$ were measured with an Elmetron CC-411 conductometer (with an EC60 sensor designed for measuring the conductivity in the range of $10 \mu \mathrm{S} / \mathrm{cm}-100 \mathrm{mS} / \mathrm{cm}$ ) and an Elmetron CP-315M pH-meter, respectively. The acidity was analysed by an acid-base titration method, with the use of $0.1 \mathrm{M} \mathrm{NaOH}$ and methyl orange as an indicator. Surface tension measurements of the solutions were conducted with an automatic EasyDyne tensiometer (Krüss) at $20^{\circ} \mathrm{C}$.

The concentrations of surfactants in aqueous solutions were determined with the apparatus 785 DMP Titrino, using the potentiometric titration method. Total dissolved solids were determined according to Standard Methods [12]. The colour intensity was measured at the wavelength of $350 \mathrm{~nm}$ (Hitachi U-1900). The content of organic compounds was monitored by means of TOC (TOC 5050 Analyser, Shimadzu) and COD (DR/2000 spectrophotometer, Hach). The protein and lactose contents were analysed by means of the Bradford reagent method [13] and the Miller method, using dinitrosalicylic acid [14], respectively.

\section{RESULTS AND DISCUSSION}

\subsection{PROPERTIES OF FEED SOLUTIONS}

The physicochemical properties of aqueous detergent solutions are presented in Table 3. The results demonstrated a linear relationship, depending on the detergent concentration $\left(C_{\text {det. }}\right)$ in water solutions. An increased concentration of the detergent resulted in a slight decrease in the $\mathrm{pH}$ value, from 2.04 to 1.46 for 1 and $4 \% \mathrm{w} / \mathrm{v}$, respectively. The value of surface tension was reduced with the increased concentration of the single-phase detergent, from 28.7 to $26.2 \mathrm{mN} / \mathrm{m}$ for 1 and $4 \% \mathrm{w} / \mathrm{v}$, respectively.

The aqueous solutions containing $0.75 \% \mathrm{w} / \mathrm{v}$ of milk (solution A) and $2 \% \mathrm{w} / \mathrm{v}$ aqueous solution of the single-phase detergent, to which $0.75 \% \mathrm{w} / \mathrm{v}$ of milk was added (solution B), are characterized in Table 4. 
Table 3

Physicochemical properties of aqueous solution of the single-phase detergent

\begin{tabular}{|l|c|c|c|c|l|}
\hline \multirow{2}{*}{ Parameter } & \multicolumn{6}{|c|}{ Detergent concentration $[\% \mathrm{w} / \mathrm{v}$} & \multirow{2}{*}{ Linear approximation } \\
\cline { 2 - 6 } & 1 & 2 & 3 & 4 & \\
\hline Acidity, val $/ \mathrm{m}^{3}$ & 16.9 & 33.6 & 49.7 & 66.9 & $\begin{array}{l}\text { Acidity }=16.7 \times C_{\text {det. }} \\
R^{2}=0.99\end{array}$ \\
\hline Conductivity, $\mathrm{mS} / \mathrm{cm}$ & 6.83 & 13.46 & 20.0 & 26.7 & $\begin{array}{l}\text { Cond. }=6.7 \times C_{\text {det. }} \\
R^{2}=0.99\end{array}$ \\
\hline Surfactant, \% & 0.012 & 0.029 & 0.040 & 0.065 & $\begin{array}{l}\text { Surf. }=0.015 \times C_{\text {det. }} \\
R^{2}=0.98\end{array}$ \\
\hline TOC, $\mathrm{g} \mathrm{C} / \mathrm{m}^{3}$ & 161 & 377 & 551 & 788 & $\begin{array}{l}\mathrm{TOC}=190.7 \times C_{\text {det. }} \\
R 2=0.99\end{array}$ \\
\hline COD, $\mathrm{g} \mathrm{O} \mathrm{O}_{2} / \mathrm{m}^{3}$ & 1365 & 2814 & 3741 & 5248 & $\begin{array}{l}\mathrm{COD}=1307 \times C_{\text {det. }} \\
\mathrm{R} 2=0.99\end{array}$ \\
\hline Colour, $\mathrm{g} \mathrm{Pt} / \mathrm{m}^{3}$ & 3.0 & 6.4 & 12.4 & 16.1 & $\begin{array}{l}\text { Colour }=3.9 \times C_{\text {det. }} \\
R^{2}=0.98\end{array}$ \\
\hline TDS, $\mathrm{g} / \mathrm{m}^{3}$ & 502 & 1090 & 1557 & 1976 & $\begin{array}{l}\mathrm{TDS}=509 \times C_{\text {det. }} \\
\mathrm{R}^{2}=0.99\end{array}$ \\
\hline
\end{tabular}

Table 4

Physicochemical properties of tested solutions

\begin{tabular}{|l|c|c|}
\hline \multicolumn{1}{|c|}{ Parameter } & Solution A & Solution B \\
\hline $\mathrm{pH}$ & 7.09 & 2.18 \\
\hline Acidity, val $/ \mathrm{m}^{3}$ & - & 32.4 \\
\hline Conductivity, $\mathrm{mS} / \mathrm{cm}$ & $73.9 \times 10^{-3}$ & 13.31 \\
\hline Surfactant, $\%$ & - & 0.029 \\
\hline Surface tension, $\mathrm{mN} / \mathrm{m}$ & 44.7 & 26.5 \\
\hline TOC, $\mathrm{g} \mathrm{C} / \mathrm{m}^{3}$ & 216 & 563 \\
\hline COD, $\mathrm{g} \mathrm{O} / \mathrm{m}^{3}$ & 1256 & 3608 \\
\hline Protein, $\mathrm{g} / \mathrm{m}^{3}$ & 237 & 237 \\
\hline Lactose, $\mathrm{g} / \mathrm{m}^{3}$ & 323 & 327 \\
\hline TDS, $\mathrm{g} / \mathrm{m}^{3}$ & 831 & 1912 \\
\hline
\end{tabular}

\subsection{TRANSPORT PROPERTIES}

The transport properties of flat-sheet NF and UF membranes are presented in Figs. 1 and 2. At the beginning of the membrane filtration cycle of single-phase detergent solutions, a sharp reduction in permeate flux was noticed, in comparison with the flux of deionized water. However, with the filtration time, there were no further significant changes in the hydraulic performance of membranes (Fig. 1). Moreover, the membranes were characterized by a very similar flux decline with the increased concentra- 
tion of the single-phase detergent in the feed solutions (Table 5). Only for the membrane with the highest MWCO value (UP010) was observed a greater difference in flux decline with increasing detergent concentration. The calculated value of permeate flux decline at the end of filtration cycle for the tested membranes exceeded $90 \%$, which means that the membranes have lost their hydraulic performance.
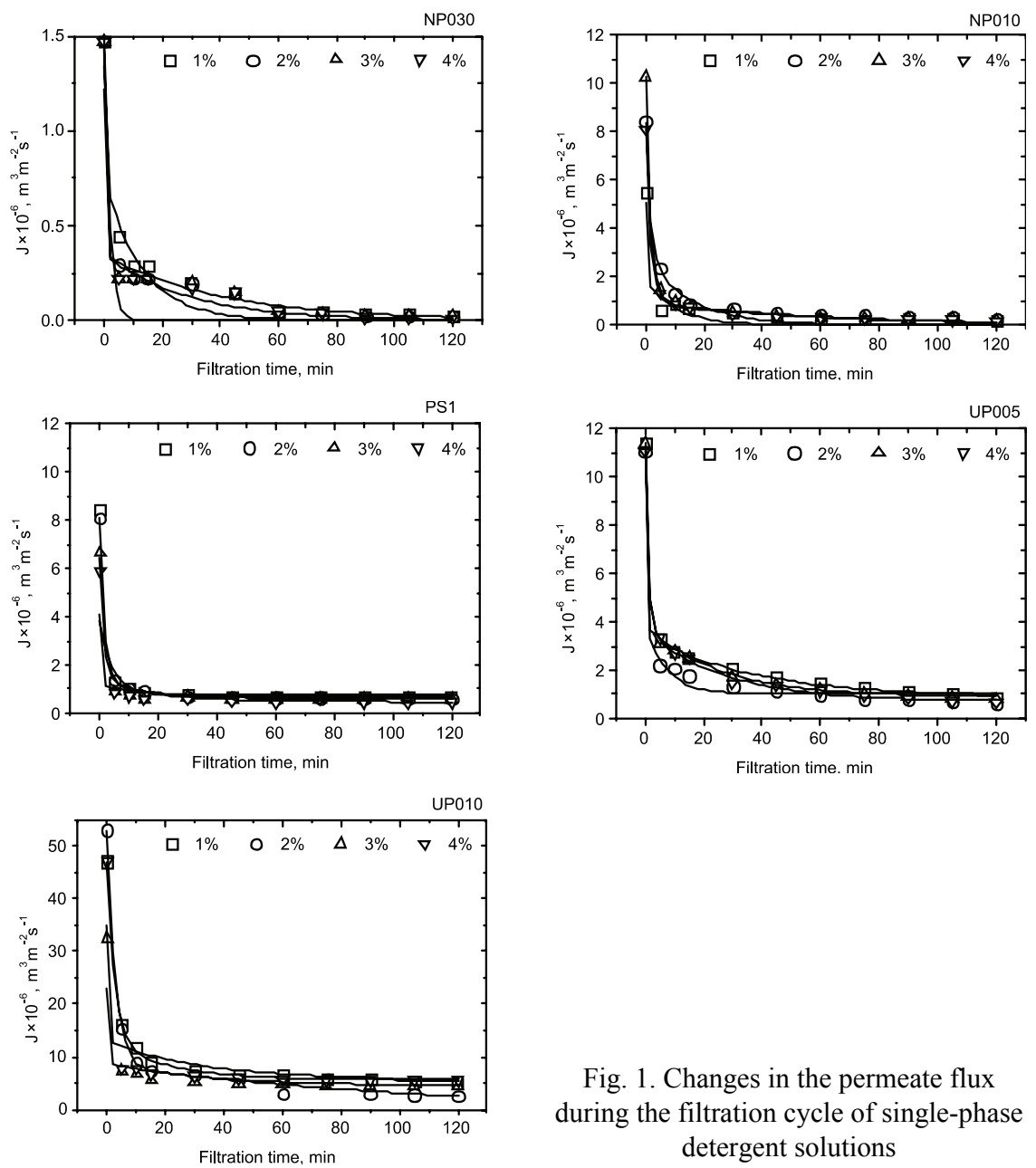

Fig. 1. Changes in the permeate flux during the filtration cycle of single-phase detergent solutions

Also a very large drop in the hydraulic performance of membranes (81-97\%) was revealed during the filtration of solution $\mathrm{B}(2 \% \mathrm{w} / \mathrm{v}$ aqueous solution of the single-phase detergent to which $0.75 \% \mathrm{w} / \mathrm{v}$ of milk was added) (Fig. 2b, Table 5), whereas $\mathrm{NF}$ and UF membranes were characterized by a slightly lower susceptibility to fouling $(51-74 \%$ ) during filtration of $0.75 \% \mathrm{w} / \mathrm{v}$ solution of milk (Fig. 2a, Table 5). 

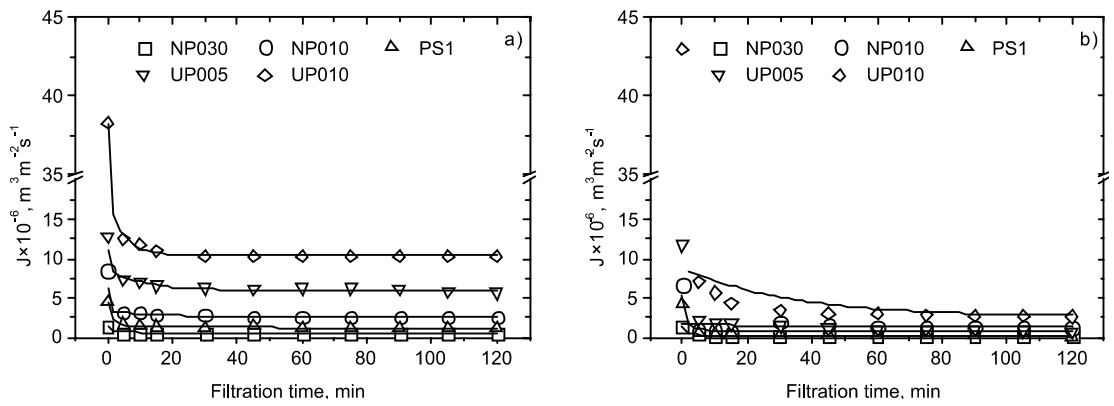

Fig. 2. Changes in the permeate flux during the filtration cycle of tested solutions: a) solution A, b) solution B

Table 5

Flux decline $(100-R F)$ of flat-sheet membranes for the filtration time $t=120 \mathrm{~min}$

\begin{tabular}{|c|c|c|c|c|c|c|}
\hline \multirow{2}{*}{ Membrane } & \multicolumn{4}{|c|}{ Detergent concentration, $\% \mathrm{w} / \mathrm{v}$} & \multirow{2}{*}{ Solution A } & \multirow{2}{*}{ Solution B } \\
\hline & 1 & 2 & 3 & 4 & & \\
\hline NP030 & 98 & 98 & 98 & 98 & 65 & 81 \\
\hline NP010 & 96 & 97 & 98 & 98 & 69 & 82 \\
\hline PS1 & 92 & 92 & 91 & 92 & 74 & 97 \\
\hline UP005 & 92 & 94 & 93 & 94 & 51 & 94 \\
\hline UP010 & 86 & 88 & 90 & 95 & 73 & 95 \\
\hline
\end{tabular}

Table 6

Flux decline $(F R-R F)$ of flat-sheet membranes caused by reversible fouling

\begin{tabular}{|c|c|c|c|c|c|c|}
\hline \multirow{2}{*}{ Membrane } & \multicolumn{4}{|c|}{ Detergent concentration, $\% \mathrm{w} / \mathrm{v}$} & \multirow{2}{*}{ Solution A } & \multirow{2}{*}{ Solution B } \\
\hline & 1 & 2 & 3 & 4 & & \\
\hline NP030 & 68 & 63 & 63 & 60 & 40 & 79 \\
\hline NP010 & 81 & 79 & 83 & 72 & 48 & 82 \\
\hline PS1 & 77 & 71 & 58 & 58 & 23 & 64 \\
\hline UP005 & 89 & 87 & 90 & 94 & 26 & 72 \\
\hline UP010 & 86 & 88 & 86 & 84 & 43 & 11 \\
\hline
\end{tabular}

Table 7

Flux decline $(100-F R)$ of flat-sheet membranes caused by irreversible fouling

\begin{tabular}{|c|c|c|c|c|c|c|}
\hline \multirow{2}{*}{ Membrane } & \multicolumn{4}{|c|}{ Detergent concentration, $\% \mathrm{w} / \mathrm{v}$} & \multirow{2}{*}{ Solution A } & \multirow{2}{*}{ Solution B } \\
\hline & 1 & 2 & 3 & 4 & & \\
\hline NP030 & 30 & 35 & 35 & 38 & 25 & 2 \\
\hline NP010 & 15 & 18 & 15 & 26 & 21 & 0 \\
\hline PS1 & 15 & 21 & 33 & 34 & 51 & 33 \\
\hline UP005 & 3 & 7 & 3 & 0 & 25 & 22 \\
\hline UP010 & $-59^{\mathrm{a}}$ & $-50^{\mathrm{a}}$ & 4 & 11 & 30 & 84 \\
\hline
\end{tabular}

${ }^{\mathrm{a}} \mathrm{An}$ increase in permeate flux in comparison with the brand-new membrane. 
The flux decline caused by reversible and irreversible fouling, as estimated from Eqs. (3) (RF) and (4) (FR) (Table 2), were compared for all tested solutions in Tables 6 and 7. As can be seen, the effect of irreversible fouling (defined as the part of fouling not removable by rinsing and backwashes but only by chemical cleanings) during the filtration of solution B was particularly dominant for the flux decline of the UP010 membrane. On the other hand, for the NF and dense UF (PS1 and UP005) membranes, the flux decline was mainly affected by reversible fouling. Moreover, for these membranes, the increase in share of reversible fouling (and the decrease in share of irreversible fouling) in comparison with filtration of $0.75 \% \mathrm{w} / \mathrm{v}$ milk aqueous solution was noticed.

The above relationships were probably related to a modification of the protein system by the presence of an acidic detergent. On the one hand, the denatured proteins form complexes with casein micelles, causing enlargement of the casein micelles under the influence of nitric acid. The nascent macroparticles are retained on the membrane surface and help us to protect the pores of dense membranes from fouling. On the other hand, the presence of peracetic acid (a known disinfectant in the food industry) did not result in the formation of high molecular weight aggregates [15]. Thus, among the tested membranes, the pores of UP010 ones are large enough to become congested with milk protein. Summing up the results from Tables 5-7, it can be stated that the flux decline during the filtration of solution B was influenced mainly by the composition of the single-phase detergent.

Chemical cleaning using $0.1 \mathrm{M} \mathrm{NaOH}$ restored the original permeability of the polymers significantly. The water flux was not lower than $90 \%$ of the water flux determined for the brand new membranes.

\subsection{SEPARATION PROPERTIES OF THE MEMBRANES}

Changes in the quality of single-phase detergent solutions in membrane filtration are presented in Fig. 3. Analyses using the parameters described in Section 2.4 were conducted on the averaged samples that were collected within the filtration of $120 \mathrm{~min}$. The composition of the permeates indicates that parameters such as $\mathrm{pH}$, conductivity and acidity, did not change significantly, and remained at similar levels as in the feed solutions (Figs. 3a-c). The application of NF and UF membranes resulted in a weakening of the detergency properties of the permeates (Fig. 3d). One may notice that for NP030, NP010 and PS1 membranes, the surface tension in the permeate decreased by about $10 \mathrm{mN} / \mathrm{m}$ in comparison with the feed solutions, whereas for the less dense UF membranes (i.e. UP005 and UP010), the surface tension in the permeate decreased by about 8 and $5.5 \mathrm{mN} / \mathrm{m}$.

The results corresponded to the retention coefficient of anionic surfactants having the ability to reduce the surface tension of the solutions. The high separation of surfactants (87-98\%) from tested solutions was attributed mainly to their presence in micellar form, and simultaneously, the large size of created micelles [16, 17]. 

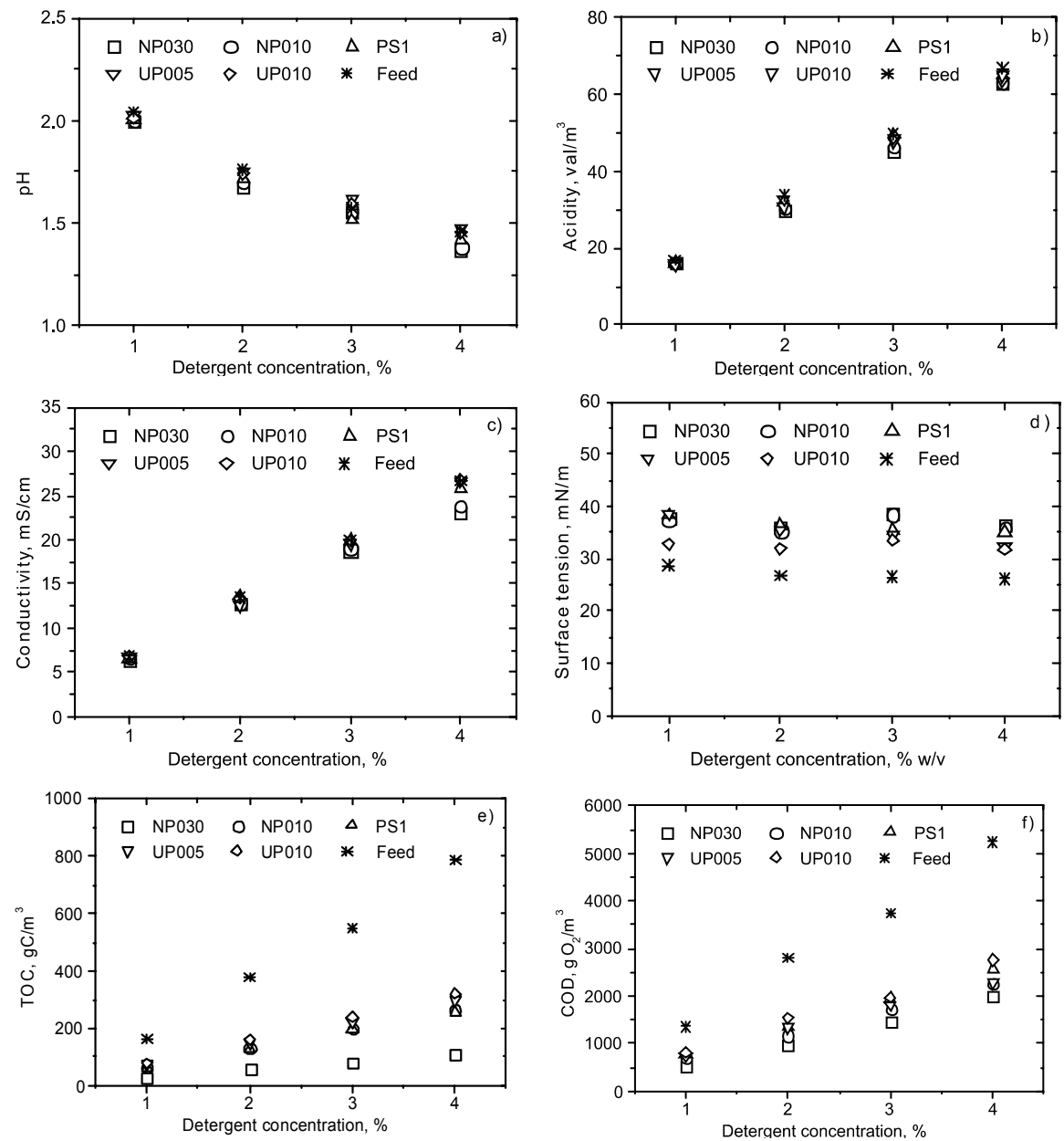

Fig. 3. Changes in the quality of the single-phase detergent solutions in membrane filtration. For details, see the text

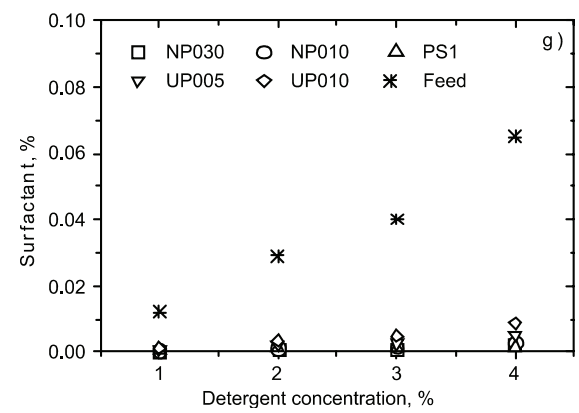

According to Hussain [18], depending on the EON number of surfactant, the CMC value increases from $0.0242 \mathrm{~g} / \mathrm{dm}^{3}$ to $0.0788 \mathrm{~g} / \mathrm{dm}^{3}$ for $\mathrm{EON}=2.5$ and $\mathrm{EON}=7$, re- 
spectively. It was further proven that by increasing the $\mathrm{pH}$, the degree of ionisation of the carboxylic head group increases, which in turn increases the solubility of surfactant in water. The weakly ionised surfactant molecule retains the best properties of nonionic surfactants and hence the large aggregate size for acid solution. For example, the size of aggregate of AEC $+\mathrm{EO} 4$ (conc. $=0.5 \mathrm{~g} / \mathrm{dm}^{3}$ ) amounted to $145 \mathrm{~nm}$ and $20 \mathrm{~nm}$ for $\mathrm{pH}=4.46$ and $\mathrm{pH}=10$, respectively [18].

As a result of the high separation of surfactant (Fig. 3g) and other organic additives, the values of TOC and COD were reduced in the permeates (Figs. 3e, f). For example, the reduction of COD amounted to $60,54,48,52$ and $47 \%$, for $3 \% \mathrm{w} / \mathrm{v}$ detergent solutions with the use of NP030, NP010, PS1, UP005 and UP010 membranes, respectively.

The effectiveness of NF and UF membranes for the separation of milk components, both from aqueous solutions and the single-phase detergent solutions, is presented in Fig. 4. The results showed that the $\mathrm{pH}$ of the filtrates remained constant, and corresponded to the values for the feed solutions (Fig. 4a). In the case of solution B, similar to the $2 \% \mathrm{w} / \mathrm{v}$ solution, the conductivity of the filtrates did not change significantly and remained at similar levels as in the feed solutions (Fig. 4c). Moreover, a small decrease in the acidity of permeates was noticed with the decreasing MWCO value of the membranes (Fig. 4b). The invariability of the parameters confirms the negligible separation of acids which are present in detergent formulation, whereas the conductivity of the filtrates of solution A decreased by reducing the MWCO value of the membranes (Fig. 4c). For example, the reduction of the conductivity was $32 \%$ and $6 \%$ for NP030 and UP010, respectively. The decrease in conductivity was related primarily to the separation of charged proteins having a major contribution to conductivity $[19,20]$, and multivalent ions.

The permeates from filtration runs of solution A were characterized by a relatively high retention of organic matter, expressed as TOC and COD (Figs. 4e, f, Table 8). For example, the retention of COD amounted to $87 \%$ and $74 \%$ with the use of NP030 and UP010 membranes, respectively. The retention coefficients of COD during the filtration of solution B were slightly lower, and amounted to $65 \%$ and $56 \%$ for NP030 and UP010 membranes, respectively. The reduction of TOC and COD was related to the removal of milk components and organic compounds of single-phase detergent (mainly surfactants, Table 8).

The content of protein determined in the treated solutions was very low (Fig. 4i, Table 8) and did not exceed $5 \mathrm{~g} / \mathrm{m}^{3}$. Moreover, the proteins were separated more efficiently from the acid detergent solution than from an aqueous one. This confirms the modification of the protein system owing to the denaturation of proteins in acidic solution. The denaturated proteins form complexes with casein micelles, so they are separated more efficiently on the membrane surface.

The retention coefficient of lactose, owing to its low molecular weight, was significantly dependent on the membrane MWCO (Fig. 4h, Table 8). A satisfactory separa- 

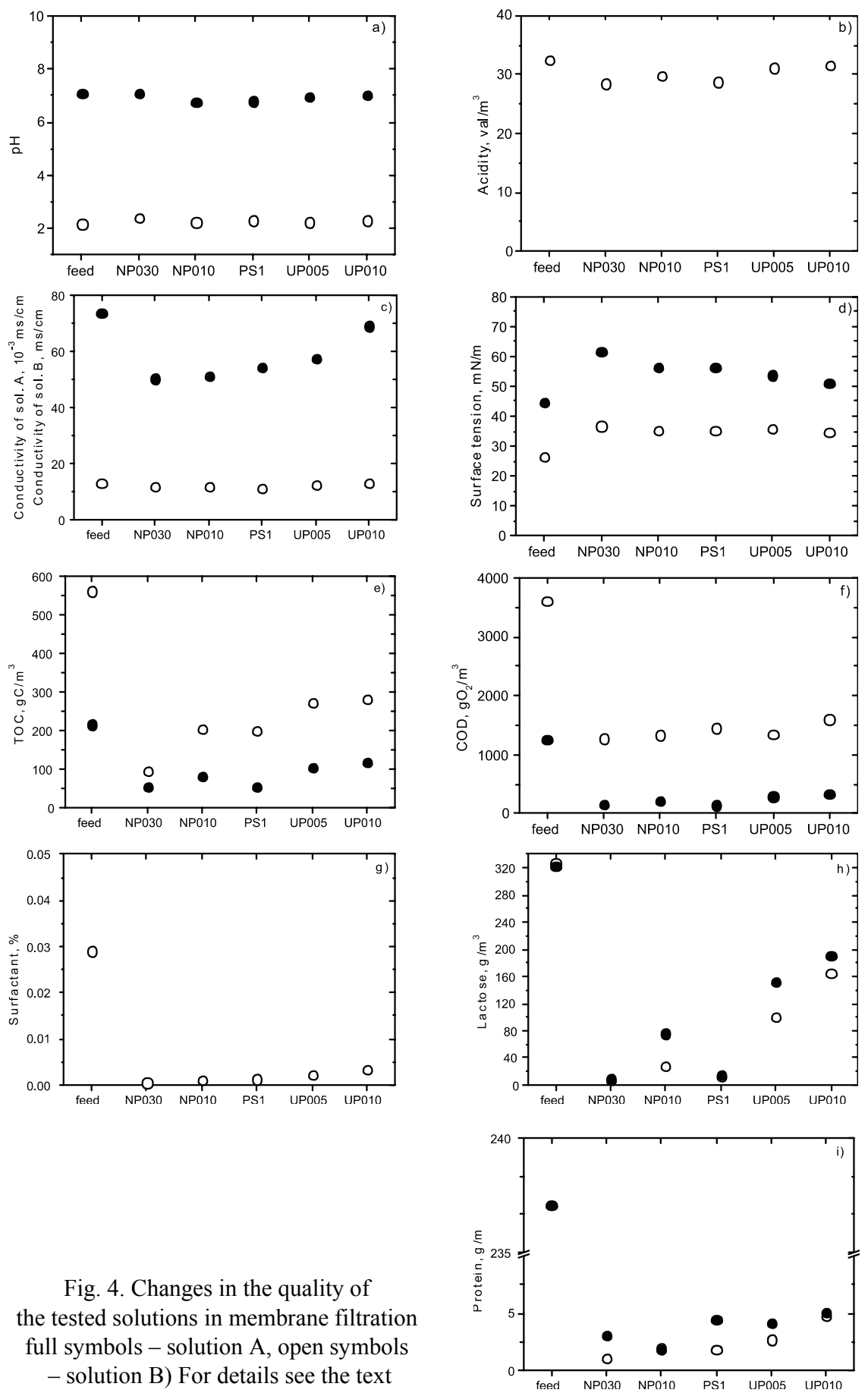

Fig. 4. Changes in the quality of the tested solutions in membrane filtration full symbols - solution A, open symbols - solution B) For details see the text 
tion was achieved on the NF membranes (NP030 and NP010) and the dense UF membrane (PS1). For these polymers, the separation of lactose from solutions A and B that took place was in the range of $77-97 \%$ and $91-98 \%$, respectively. Literature reports confirm the results obtained for the filtration of solution A. Limsawat et al. [21] reported $100 \%$ separation of protein from UHT milk with the use of $5 \mathrm{kDa}$ UF membrane, whereas the retention coefficient of lactose depended greatly on transmembrane pressure and amounted to $15.5-48.7 \%$. However, Gong et al. [22], during the filtration of dairy wastewater $\left(\mathrm{COD}=2500-3900 \mathrm{~g} \mathrm{O}_{2} / \mathrm{m}^{3}\right.$; protein $=1010-1310 \mathrm{~g} / \mathrm{m}^{3}$; lactose: $470-590 \mathrm{~g} / \mathrm{m}^{3}$ ) achieved protein separation on $10 \mathrm{kDa}$ UF membrane, in the range of 96.1-98.5\%, depending on the transmembrane pressure and $\mathrm{pH}$ of the solution. However, to obtain satisfactory removal of lactose from wastewater, NF membranes were used with the separation efficiency of 54\% (NF270) and 98.5\% (NF90).

Table 8

Retention coefficients $(R, \%)$ of organic compounds on NF and UF membranes

\begin{tabular}{|c|l|c|c|c|c|c|}
\hline \multirow{2}{*}{ Solution } & \multirow{2}{*}{ Parameter } & \multicolumn{5}{|c|}{ Membrane } \\
\cline { 3 - 7 } & & NP030 & NP010 & PS1 & UP005 & UP010 \\
\hline \multirow{4}{*}{ A } & TOC & 75 & 62 & 75 & 52 & 44 \\
\cline { 2 - 7 } & COD & 87 & 82 & 88 & 76 & 74 \\
\cline { 2 - 7 } & Lactose & 97 & 77 & 95 & 53 & 41 \\
\cline { 2 - 7 } & Protein & 99 & 99 & 98 & 98 & 98 \\
\hline \multirow{5}{*}{ B } & TOC & 83 & 63 & 64 & 52 & 50 \\
\cline { 2 - 7 } & COD & 65 & 63 & 60 & 63 & 56 \\
\cline { 2 - 7 } & Lactose & 98 & 91 & 96 & 69 & 49 \\
\cline { 2 - 7 } & Protein & 100 & 99 & 99 & 99 & 98 \\
\cline { 2 - 7 } & Surfactant & 98 & 96 & 96 & 93 & 88 \\
\hline
\end{tabular}

For solution A, the surface tension of the permeates increased by decreasing the MWCO of the membranes (Fig. 4d). This phenomenon was most likely caused by the separation of peptides which, according to literature data, have the ability to lower the surface tension of solutions. However, the surface tension of the permeate increased by about $10 \mathrm{mN} / \mathrm{m}$ for all applied membranes, with respect to solution $\mathrm{B}$. The increase in surface tension was mainly a result of (beside the removal of peptides) the retention of anionic surfactants (Fig. 4g, Table 8).

\section{CONCLUSIONS}

The studies have shown the potential usefulness of membrane filtration for purification and recovery of a spent acid single-phase detergent. The NF (NP030 and NP010) and the tight UF (PS1) provided a high separation of specific milk compo- 
nents (protein and lactose) and organic matter, expressed as TOC and COD. The purified detergent maintained its low $\mathrm{pH}$ and high value of acidity. However, the surface tension increased slightly as a result of the high separation of the anionic surfactant.

Membrane flux decline during filtration was mainly affected by reversible fouling. Furthermore, chemical cleaning using $0.1 \mathrm{M} \mathrm{NaOH}$ significantly restored the original permeability of the polymers. The water flux was not lower than $90 \%$ of the water flux determined for the brand new membranes. Used membranes made of polysulfone and polyethersulfone were also characterized by high chemical stability.

\section{SYMBOLS}

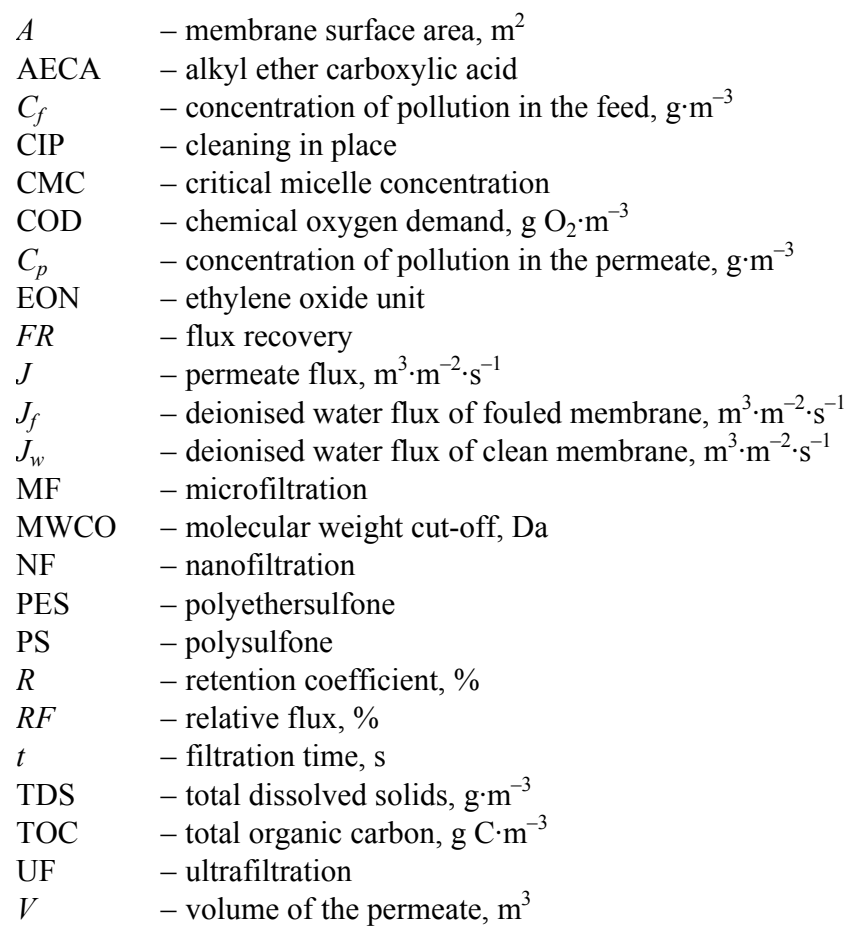

\section{ACKNOWLEDGEMENT}

The project was funded by the National Science Centre No. N N523 740440.

\section{REFERENCES}

[1] Van Asselt J., Van Houwelingen G., Te Giffel M.C., Trans IChemE, 2002, 80, 276.

[2] Dresch M., Daufin G., Chaufer B., Sep. Purif. Technol., 2001, 22-23, 181. 
[3] Boyce A., Piterina A.V., Walsh G., Biofouling, 2010, 26 (7), 837.

[4] Gésan-Guiziou G., Alvarez N., Jacob D., Daufin G., Sep. Purif. Technol., 2007, 54, 329.

[5] Novalic S., Dabrowski A., Kulbe K.D., J. Food Eng., 1998, 38, 125.

[6] GÉSAn-Guiziou G., Boyaval E., Daufin G., Desalination, 2002, 149, 127.

[7] TRÄGÅRDH G., JOHANSSON D., Desalination, 1998, 119, 21.

[8] Daufin G., Escudier J.P., Carrere H., Berot S., Fillaudeau L., Decloux M., Trans. IchemE, 2001, 79, 89.

[9] Dresch M., Daufin G., Chaufer B., Lait, 1999, 79, 245.

[10] Novalic S., Dabrowski A., Kulbe K.D., J. Food Eng., 1998, 38, 133.

[11] RÄsÄnen E., Nyström M., SAhlstein J., Tossavainen O., Desalination, 2002, 149, 185.

[12] APHA, Standard Methods for Examination of Water and Wastewater, 17th Ed., American Public Health Association, Washington, DC, 1989.

[13] BRADFORD M., Anal. Biochem., 1976, 72, 248.

[14] Miller G.L., Anal. Chem., 1972, 31, 426.

[15] Kerkaert B., Mestdagh F., Cucu T., Aedo P.R., Ling S.Y., De Meulenaer B., J. Agric. Food Chem., 2011, 59, 907.

[16] Kowalska I., Ochr. Środ., 2011, 33 (1), 41 (in Polish).

[17] KowalsKa I., Environ. Prot. Eng., 2008, 34 (2), 105.

[18] Hussain A., Luckham P.F., TAdros T.F., Rev. Inst. Francais Pétrole, 1997, 52 (2), 228.

[19] Bazinet L., Castaigne F., Pouliot Y., Appl. Eng. Agricult., 2005, 21, 455.

[20] Bazinet L., Pouliot Y., Castaigne F., J. Membrane Sci., 2010, 352, 32.

[21] Limsawat P., Pruksasri S., As. J. Food Ag-Ind., 2010, 3 (2), 236.

[22] Gong Y.W., Zhang H.X., Cheng X.N., Water Sci. Technol., 2012, 65 (5), 915. 